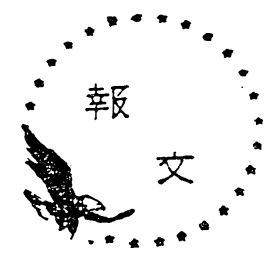

予熱乾留法実炬試験（II）

一部分予熱法試験一

一昭和 40 年 8 月 23 日受理一

\section{I . 緒言}

予熱炭をコークス炉に装入するいわゆる予熱炭乾留 法に関する実炉試験は, 先に予備試験 ${ }^{1)}$ によつて, 予 熱炭の搬送, 湿炭との混合, 装大作業などの取り报い 処理について試験したが，なんら問題点もなく，実㓠 操業に上りいれられる見通しを得た。したがつて，今 回は予備試験に使用した設備装置をそのまま利用し, 当研究所の当初の目的である国内炭活用の立場から, 国内炭を多量に配合した高炉用コークスの製造試験, 一般炭の配合試験，コークス炉の生産性向上について

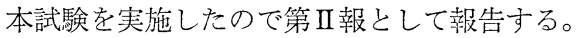

この試験においては，前報でのべたように，予熱装 置は基礎実験 ${ }^{2)}$ に使用した流動式予熱炉と異なり，現 有のデイスコ法の回転炉を流用した。また試験にはい
わ汸部分予熱法 ${ }^{2)}$ を採用し，藻業中の日常作業にお りこんで試験したため, 試験用装大炭量が限定された ので, 予熱效果を確認する意味から, 特に重点的に石 炭の配合割合老決定し，実炉への適用性在把握するよ うつと的た。

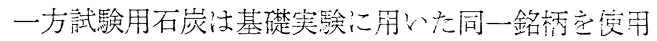
する予定であつたが，多量に即時入手することボだき なかつたことと，操業中の炉に影響をおよぼさないこ とを前提条件としたので，比較的同品種の石岸を避 び, 小規模試験によつて予熱効果を確認した後, 本試 験を実施した。

\section{II. 試験設備および装置}

前報の予俑試験に使用した設備および装置をこのま 安利用した。それらの概要を Fig. 1 に示寸。

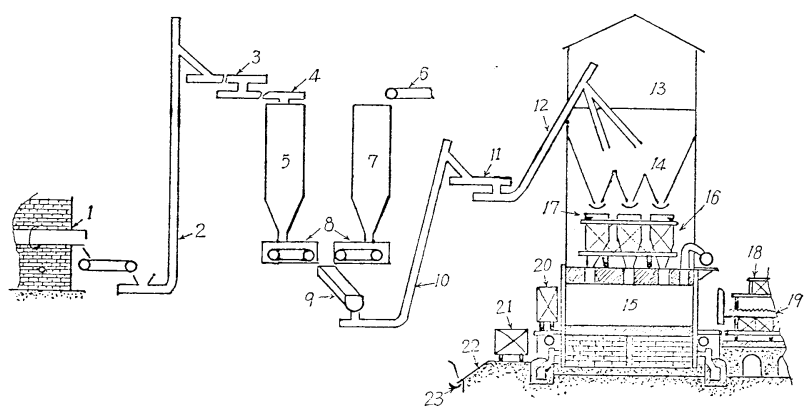

Fig. 1 Schematic arrengements for Test

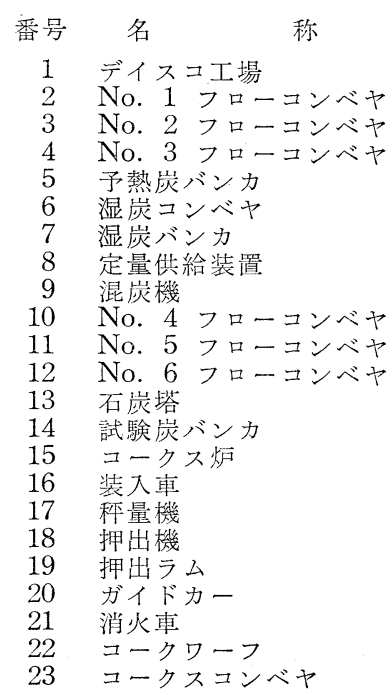




\section{III. 試験用石炭}

1. 銘柄 本試験に使用した石炭の銘柄および性状
は Table 1 に示す。

Table 1 Qualities of Used Coals

\section{Used Coal}

Vicary Creek Coal

Yubari-Tokugo-Bifun Coal

Bibai Coal
Moisture

$\%$

8.0

7.2

8.0

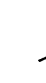

$\mathrm{H}_{2} \mathrm{O}$

Proximate Analyses \%

$\begin{array}{ccccc}\text { Ash } & \text { V. M. } & \text { F.C. } & \text { Total S. } & \text { B. I. } \\ 9.6 & 22.6 & 66.6 & 0.5 & \\ 5.3 & 39.0 & 54.7 & 0.2 & 7 \\ 9.5 & 40.2 & 47.6 & 0.3 & 2^{1 / 2}\end{array}$

2. 粒度およびかさ密度 試験に使用した石炭の粒 度分布を Fig. 2 に, 各単味炭の湿分とかさ密度 の関係を Fig. 3 に示す。

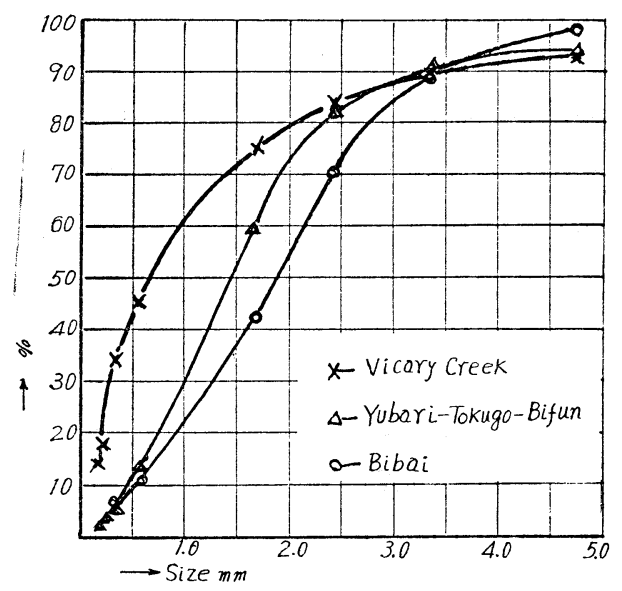

Fig. 2 Distribution curve of particle size

3. 配合割合 試験に使用した装入炭の配合割合を Table 2 に示す。すなわち, 試験番号 1４，8～ 11 は弱粘結炭に強粘結炭を $10 ４ 0 \%$ 配合した 常法および弱粘結炭のみ予熱した部分予熱の配合

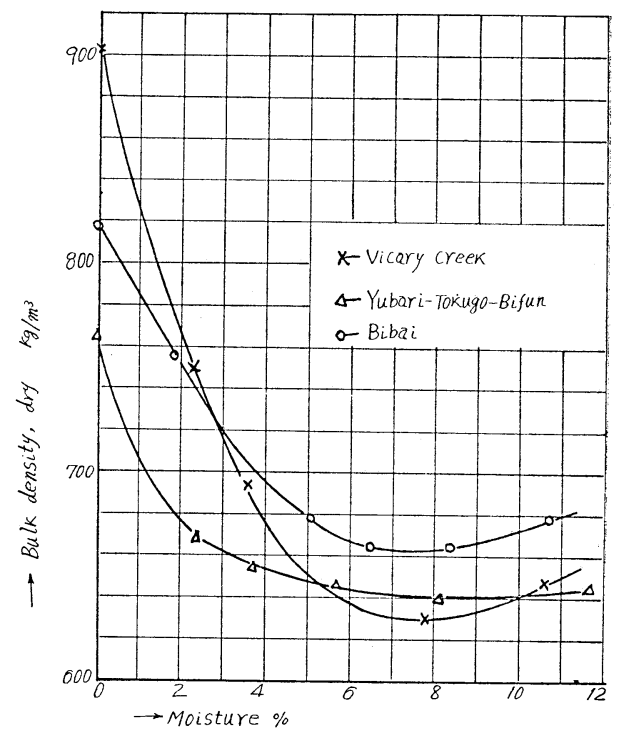

Fig. 3 Relation of bulk density and moisture

とし, 試験番号 5 7, 12〜14 は弱粘結炭の配合 量を $60 \%$ とし, 強粘結炭の配合量を一般炭でお きかえた場合の常法および強粘結炭は予熱しない で配合する部分予熱とした。

Table 2 Mixing Ratio of coals

Treatment

Coal Test No.

Vicary Creek \%

Yubari-Tokugo-Bifun \% Bibai \%

\begin{tabular}{cccc} 
& \multicolumn{3}{c}{ Untrea } \\
\hline 1 & 2 & 3 & 4 \\
10 & 20 & 30 & 40 \\
90 & 80 & 70 & 60 \\
- & - & - & - \\
& & & \\
效果予備試験 \\
炭を運び, 内径 \\
$50 \mathrm{~kg} / \mathrm{h})$ を使用
\end{tabular}

現場より当所浮間試験場に試験用炭を運び, 内径
$200 \mathrm{~mm}$ の流動式予熱炉（処理 量 $50 \mathrm{~kg} / \mathrm{h}$ ) を使用
し, 部分予熱試料をつくり, LCT $1 \mathrm{~kg}$ 炉および EW

現場より当所浮間試験場に試験用 炭を運び, 内径
$200 \mathrm{~mm}$ の流動式予熱炉（処理 量 $50 \mathrm{~kg} / \mathrm{h}$ ) を使用
し, 部分予熱試料をつくり, LCT $1 \mathrm{~kg}$ 炉および EW

\section{IV. $200 \mathrm{~mm}$ 流動炉!よる予熱効果予備試験}

Partial Preheated

\begin{tabular}{ccccccc}
\multicolumn{7}{c}{ Partial Preheated } \\
\hline 8 & 9 & 10 & 11 & 12 & 13 & 14 \\
10 & 20 & 30 & 40 & 10 & 20 & 30 \\
90 & 80 & 70 & 60 & 60 & 60 & 60 \\
- & - & - & - & 30 & 20 & 10
\end{tabular}

250 型 $15 \mathrm{~kg}$ 乾留試験炉にてコークス化の後, それ ぞれのコークス強度を常法と比較して調べた結果は Fig. 4 および Fig. 5 のようである。 


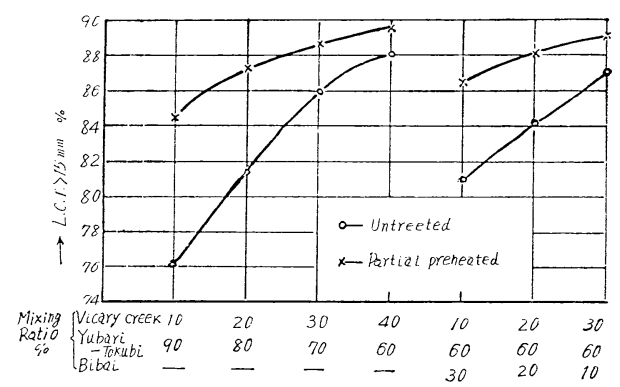

Fig. 4 Coke strengths of mixing coals by L. C. T.

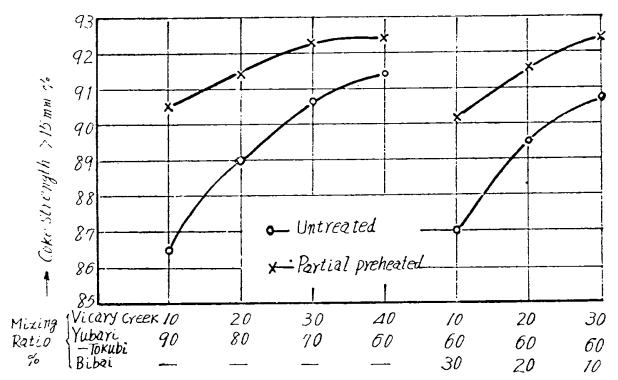

Fig. 5 Coke strengths of mixing coals by $15 \mathrm{~kg}$ test oven

この試験では，使用した石炭の銘柄は異なるが，基 礎実験と同じような結果を示している。たとえば，部 分予熱による弱粘結炭 $80 \%$ 之強粘結炭 $20 \%$ の配合 コークスと常法による弱粘結炭 $60 \%$ と強粘結炭 40 \%の配合コークスとはほぼ同等のコークス強度とな つている。また一般炭を配合した部分予熱では強粘結 炭 $20 \%$ を一般炭に打きかえても同様な強度のコ一 クスが得られる結果となつている。すなわち予熱効果 は顕著であるが，それらのコークス強度がいずれも高 炉用コークスとしての強度，すなわちドラ ム強度 $15 \mathrm{~mm}$ 指数で 93 に達していない のは残念である。これは使用した強粘結炭 であるVicary Creek 炭がそれほど有効で なかつたことと，粒度分布が予定より小さ い方に片よつていたため装入かさ密度がそ れほど増加しなかつたためであると考えら れる。

したがつて，予熱炭乾留法においては， 炭質の検討之，粒度，湿分，およびかさ密 度の関係は非常に重要である。すなわら装 入炭粒度の変化による湿分とかさ密度の関 係はコッパースハンドブックア やドイツの 文献りによつても明らかに差のあることが
わかる。それゆえ今回の試験では装大炭の粒度分布が 特に重要であることは判明したが，現場の都合上実炉 テストを急いだため, やむを得ず詳細な検討を行なわ ないまま，コークス強度については第二義的に考え， 予熱効果に重点を㧍いて実炉試験にはいることにし た。

\section{V．実炉試験の方法}

試験の方法は予備試験に準じて行なつた。一般炭の 配合の場合は，一般炭と弱粘結炭とを所定の割合で配 合したものをつくり,これを使用した。なお試験灯数 は各配合炭につき 2 門ゔつ行なつた。

\section{VI. 試験結果}

1. 輸送および炭じん 予備試験の場合と同様いず れの試験においてもなんら問題点はなく, 所定の 作業は順調に実施することができた。

2. コークス化試験

（A）弱粘結炭と強粘結炭の配合の場合の常法お よび部分予熱法のコークス炉試験実績および生 成コークスの性状を Table 3 および Table 4 に示す。

（B）弱粘結炭の配合量を $60 \%$ とし，強粘結炭 の配合量を一般炭でおきかえた場合の常法およ び部分予熱法のコークス炉試験実績および生成 コークスの性状を Table 5 および Table 6 に 示す。

3. 炉内炭中および炉頂空間部の温度変化

炉内炭中温度は押出側の炉蓋より炉中心部に長さ $1,500 \mathrm{~mm}$ の熱電詨をそう入し，炉底より 250 $\mathrm{mm}$ 上および $1,200 \mathrm{~mm}$ 上の個所を測定した。 それらの温度上昇状況はそれぞれ Fig. 6 および Fig. 7 に示す。

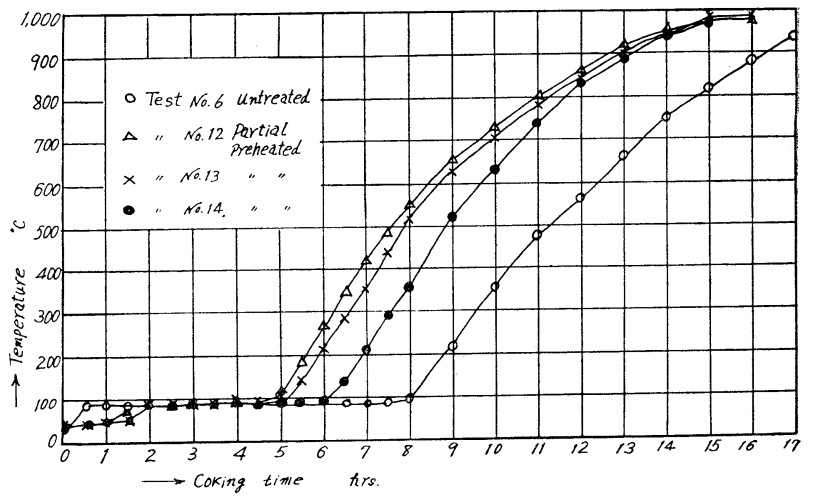

Fig. 6 Temperature curve of coal in ovens, $250 \mathrm{~mm}$ above oven sole 


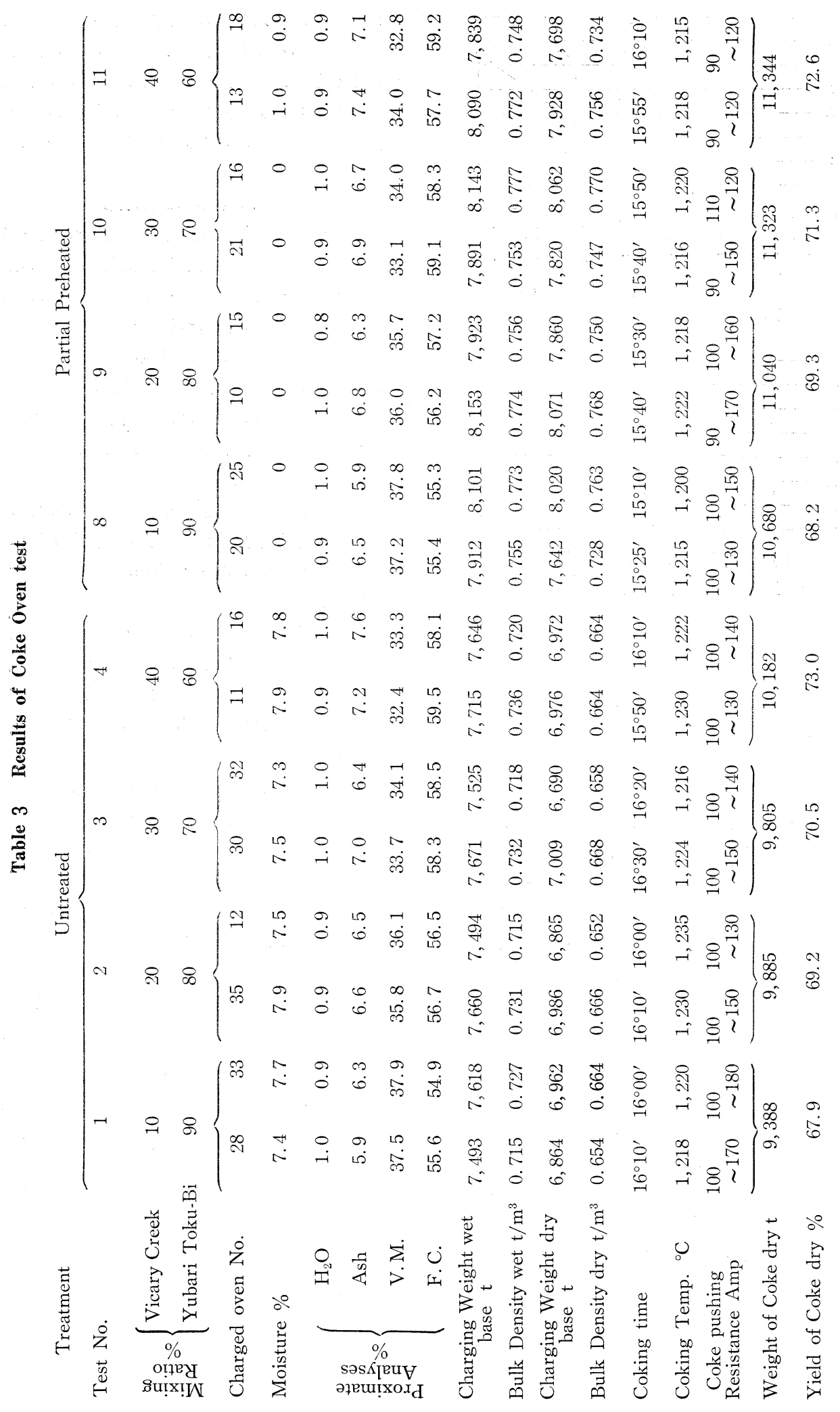


Table 4 Results of Coke quality tests

Treatment

Test No.

$\underset{\text { Mixing }}{\text { Ratio }}\left\{\begin{array}{l}\text { Vicary Creek } \\ \text { Yubari Tok }\end{array}\right.$
Charged oven No.
Micum
$\begin{gathered}\text { Strength } \\ \%\end{gathered}\left\{\begin{array}{r}\text { M40 } \\ \text { M10 }\end{array}\right.$

Drum test $>>50 \mathrm{~mm}$

$\begin{aligned} & \text { Coke Stre- } \\ & \text { ngth }\end{aligned}>25$

\% $>15$

Tumbler
test
$\%$$\left\{\begin{array}{l}>25 \mathrm{~mm} \\ >6\end{array}\right.$

Proximate
analyses
$\%$$\left\{\begin{array}{l}\mathrm{Ash} \\ \text { V.M } \\ \text { F.C. }\end{array}\right.$

Lump Coke front of oven $>25 \mathrm{~mm} \%$

(Reference)

Coke Strength

$>15 \mathrm{~mm} \%$

by $15 \mathrm{~kg}$ test Oven
Untreated

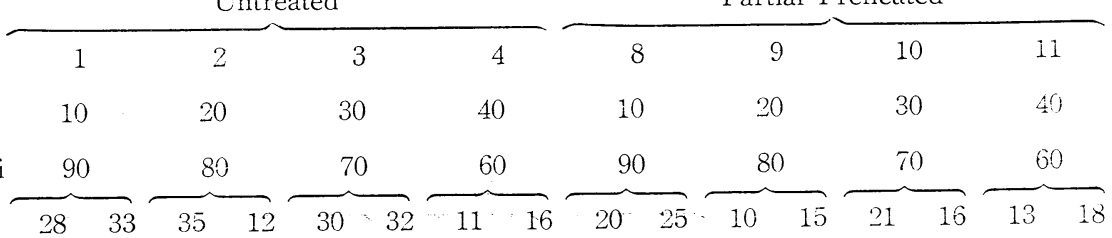

$39.241 .948 .346 .852 .7 \quad 56.4 \quad 60.4 \quad 62.8 \quad 43.4 \quad 46.2 \quad 49.252 .958 .256 .263 .064 .8$ $\begin{array}{lllllllllllllllll}11.6 & 12.8 & 9.7 & 10.4 & 9.6 & 8.5 & 8.3 & 8.4 & 9.7 & 10.2 & 9.2 & 7.6 & 7.2 & 8.3 & 7.8 & 7.4\end{array}$ $\underbrace{11.6}_{19.5} \underbrace{9.7}_{26.9} \underbrace{1.6}_{33.4} \underbrace{8.7}_{28.4} \underbrace{9.2}_{34.0} \underbrace{7.2}_{38.3} \underbrace{10.3}_{42.5}$

$\begin{array}{llllllll}69.8 & 77.1 & 80.4 & 84.2 & 78.5 & 81.0 & 85.5 & 88.6\end{array}$

$\begin{array}{llllllll}84.5 & 87.4 & 89.2 & 90.5 & 88.6 & 90.4 & 91.8 & 92.9\end{array}$

$\begin{array}{llllllll}61.8 & 68.4 & 72.3 & 74.5 & 70.6 & 74.8 & 76.8 & 79.2\end{array}$

$\begin{array}{llllllll}83.1 & 83.7 & 84.0 & 85.1 & 85.0 & 85.2 & 85.9 & 87.1\end{array}$

$\begin{array}{llllllll}9.1 & 9.5 & 9.8 & 10.7 & 8.9 & 9.3 & 10.3 & 10.7\end{array}$

$\begin{array}{llllllll}1.5 & 1.4 & 1.5 & 1.1 & 1.9 & 1.3 & 1.7 & 1.3\end{array}$

$\begin{array}{llllllll}89.4 & 89.1 & 88.7 & 88.2 & 89.2 & 89.4 & 88.0 & 88.0\end{array}$

$\begin{array}{llllllll}95.6 & 93.1 & 94.9 & 96.9 & 96.9 & 96.8 & 93.9 & 98.7\end{array}$

$\begin{array}{llllllll}85.6 & 87.7 & 89.5 & 90.2 & 90.1 & 91.7 & 92.4 & 92.5\end{array}$

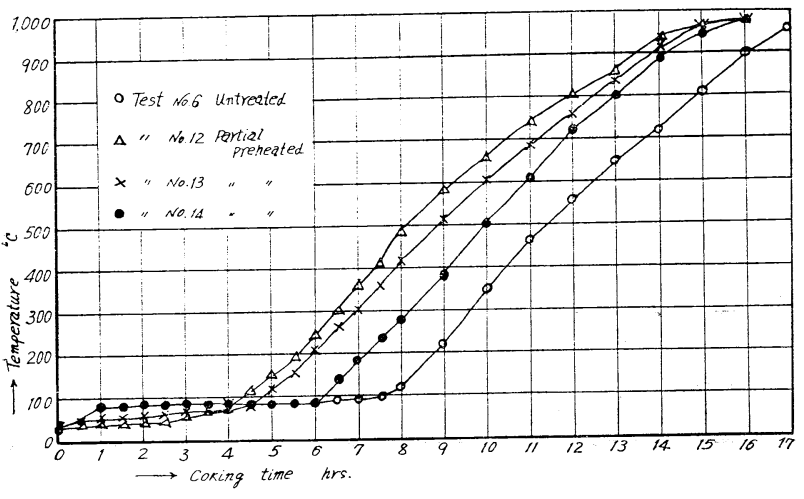

Fig. 7 Temperature curve of coal in ovens, $1,200 \mathrm{~mm}$ above oven sole

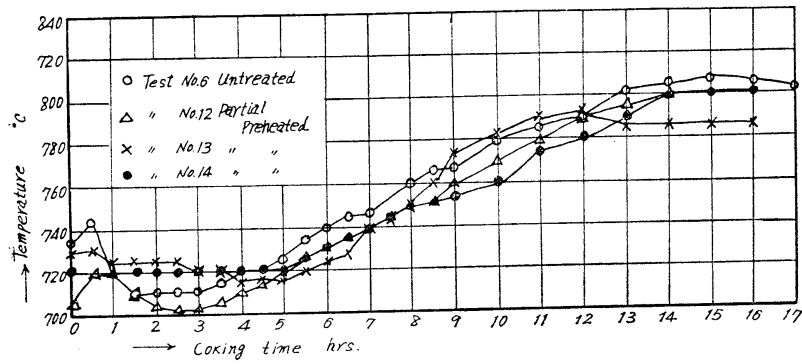

Fig. 8 Temperature curve in the gas collecting space above the coal charge
また灯頂空間部の温度は装入孔 3 个 のらち押出側の装入孔（上昇管泣押出 側）より同空間部の中央に熱電悋をそ ら入し温度変化を測定した。その結果 をFig. 8 に示す。

$$
\text { VII. 考察 }
$$

1. 装入炭量およびかさ密度

本試験においては，極端なかさ密度 の増加によるコークス炉への影響はさ けることにしたため，常法かさ密度に 対し，部分予熱では約 10\% あまり增 加した結果となつている。したがつて 装入量においては約 15\% 増加してい る。しかも炭化時間は部分予熱の方が 約30分ほど短縮されている。これらの ことはいわゆるコークス炉の生産性を あらわす（装入密度 dry）％（炭化時 間）の表現法 ${ }^{5}$ からみれば，約 $20 \%$ 増となつていて，明らかにコークス炉 の生産性がはなはだしく向上している ことがうかがわれる。さらにコークス 炉上してかさ密度の限界点上いわ礼下 いる $53 \mathrm{lb} / \mathrm{ft}^{3}\left(0.8488 \mathrm{~g} / \mathrm{cm}^{3}\right)$ 近くま 
Table 5 Results of Cokeoven test

Treatment

Test No.

Mixing $\%\left\{\begin{array}{l}\text { Vicary Creek } \\ \text { Yubari Toku-Bi } \\ \text { Bibai }\end{array}\right.$

Charged oven No.

Moisture \%

Proximate $\left\{\begin{array}{l}\mathrm{H}_{2} \mathrm{O} \\ \text { Ash } \\ \text { V.M. M. } \\ \text { F.C. }\end{array}\right.$

Chaging weight wet base $\mathrm{t}$

Bulk Density wet $\mathrm{t} / \mathrm{m}^{3}$

Charging weight dry base $t / \mathrm{m}^{3}$

Bulk Density dry $\mathrm{t} / \mathrm{m}^{3}$

Coking time

Coking Temp. ${ }^{\circ} \mathrm{C}$

Coke Pushing Resistance Amp

Weight of Coke dry $t$

Yield of Coke dry \%
Untreated

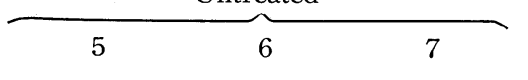

$10 \quad 20 \quad 30$

$\begin{array}{lll}60 & 60 & 60\end{array}$

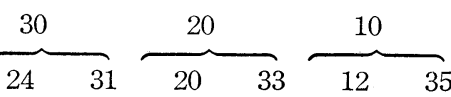

$\begin{array}{llllll}7.4 & 7.2 & 7.3 & 7.6 & 6.8 & 7.4\end{array}$

$\begin{array}{llllll}1.2 & 1.3 & 1.3 & 1.2 & 1.2 & 1.3\end{array}$

$\begin{array}{llllll}7.9 & 7.6 & 7.6 & 7.8 & 7.7 & 7.9\end{array}$

$\begin{array}{llllll}38.1 & 37.8 & 36.2 & 35.6 & 34.8 & 34.5\end{array}$

$\begin{array}{llllll}52.8 & 53.3 & 54.9 & 55.4 & 56.3 & 53.6\end{array}$

7,577 7,525 7,451 7,640 7,461 7,672

$\begin{array}{lllllll}0.723 & 0.718 & 0.711 & 0.729 & 0.712 & 0.732\end{array}$

$\overbrace{12}^{\text {Partial Preheated }}$

$10 \quad 20 \quad 30$

60

60

30

$\overbrace{2320}^{30} \overbrace{1924}^{20} \overbrace{13 \quad 18}^{10}$

$\begin{array}{llllll}0 & 0 & 0 & 0 & 0.9 & 1.0\end{array}$

$\begin{array}{llllll}1.0 & 1.1 & 1.2 & 1.0 & 1.2 & 1.2\end{array}$

$\begin{array}{llllll}7.9 & 8.1 & 7.6 & 7.9 & 8.2 & 7.8\end{array}$

$\begin{array}{llllll}37.5 & 36.9 & 35.2 & 36.0 & 34.2 & 33.8\end{array}$

$\begin{array}{llllll}56.3 & 53.9 & 56.0 & 55.1 & 56.4 & 57.2\end{array}$

$7,9128,0808,048$ 7,954 7,944 8,069 $\begin{array}{llllllll}0.755 & 0.771 & 0.768 & 0.759 & 0.758 & 0.770\end{array}$

$7,8337,9917,951$ 7,874 7,777 7,891 $\begin{array}{lllllllllllll}0.662 & 0.657 & 0.651 & 0.665 & 0.656 & 0.670 & 0.748 & 0.762 & 0.758 & 0.751 & 0.742 & 0.754\end{array}$ $16^{\circ} 55^{\prime} 16^{\circ} 20^{\prime} 16^{\circ} 20^{\prime} 16^{\circ} 50^{\prime} 16^{\circ} 50^{\prime} 16^{\circ} 40^{\prime} 15^{\circ} 10^{\prime} 15^{\circ} 30^{\prime} 15^{\circ} 45^{\prime} 15^{\circ} 15^{\prime} 15^{\circ} 40^{\prime} 15^{\circ} 50$, 1,210 1,215 1,224 1,216 1,213 1,218 1,213 1,215 1,226 1,214 1,244 1,220 $\begin{array}{llllllllllll}100 & 90 & 100 & 100 & 100 & 100 & 100 & 90 & 100 & 100 & 100 & 90\end{array}$ $\underbrace{140 \sim 140}_{9,300} \sim \underbrace{130 \sim 120}_{9,424} \sim \underbrace{150 \sim 130}_{9,666} \sim \underbrace{160 \sim 140}_{10,680} \sim \underbrace{160 \sim 140}_{10,920} \sim \underbrace{150 \sim 150}_{10,990}$
67.3
68.4
69.7
67.5
69.0
70.2

Table 6 Results of Coke Quality tests

Treatment

Test No.

Mixing $\left\{\begin{array}{l}\text { Vicary Creek } \\ \text { Yubari Toku-Bi } \\ \text { Bibai }\end{array}\right.$

Charged oven No.

Micum $\underset{\%}{\text { Strength }}\left\{\begin{array}{l}\text { M4 } \\ \text { M10 }\end{array}\right.$

Drum test Coke
Strength \% $\left\{\begin{array}{l}>50 \mathrm{~mm} \\ >25 \\ >15\end{array}\right.$

Tumbler test $\%\left\{\begin{array}{l}>25 \mathrm{~mm} \\ >6\end{array}\right.$

Proximate Analy-
ses \% $\left\{\begin{array}{l}\text { Ash } \\ \text { V. M. } \\ \text { F. C. }\end{array}\right.$

Lamp Coke front of oven $>25 \mathrm{~mm} \%$

(Reference)

Coke Strength

$>15 \mathrm{~mm} \%$

by $15 \mathrm{~kg}$ test oven
Untreated

\begin{tabular}{rrr}
5 & 6 & 7 \\
10 & 20 & 30 \\
60 & 60 & 60 \\
30 & $\overbrace{2431}^{20}$ & $\overbrace{20}^{12} 35$ \\
\hline 35
\end{tabular}

$\begin{array}{llllll}38.6 & 37.9 & 44.3 & 47.2 & 52.4 & 55.9\end{array}$

$\underbrace{14.8 \quad 14.3}_{17.1} \underbrace{11.0 \quad 12.3}_{24.8} \underbrace{10.8 \quad 8.5}_{31.9}$

63.3

81.7

75. 0

80.3

86.7

88.9

56.0

75.8

67.2

79.6

70.5

82.7

11.7

2.2

10.8

11.5

1.5

2.0

87.7

86.5

92.7

85.5

94.2

87.7

89.8
Partial Preheated

\begin{tabular}{|c|c|c|}
\hline 12 & 13 & 14 \\
\hline 10 & 20 & 30 \\
\hline 60 & 60 & 60 \\
\hline 30 & 20 & 10 \\
\hline
\end{tabular}

$\begin{array}{llllll}46.2 & 44.9 & 50.5 & 53.8 & 55.7 & 58.9\end{array}$ $\underbrace{9.8 \quad 11.2}_{33.1} \underbrace{8.6 \quad 7.8}_{37.7} \underbrace{8.0 \quad 7.2}_{42.0}$

$\begin{array}{lll}82.0 & 85.8 & 88.3\end{array}$

$\begin{array}{lll}89.8 & 91.6 & 92.5\end{array}$

$\begin{array}{lll}72.1 & 77.5 & 80.2\end{array}$

$\begin{array}{lll}80.3 & 83.9 & 85.5\end{array}$

$\begin{array}{lll}11.8 & 11.2 & 11.4\end{array}$

$\begin{array}{lll}1.5 & 1.6 & 1.1\end{array}$

$\begin{array}{lll}86.7 & 87.2 & 87.5\end{array}$

$\begin{array}{lll}94.7 & 96.9 & 97.4\end{array}$

$90.3 \quad 91.7$

92.3 
でかさ密度をあげるよう調整すればさらに生産性 の向上洪期待される。

2. コークス強度 部分予熱法によるコークスは常 法のコークスに比し, マイカム強度, 潰裂強度, タンブラー強度のいずれも増加していることがわ かる。コークス強度からいえば，予熱弱粘結炭に 強粘結炭を $20 \sim 30 \%$ 配合したコークスは，常法 の強粘結炭 $40 \%$ 配合のコークス強度に匹敵し， また強粘結炭 40\% のうちその半量を一般炭にお きかえ部分予熱法を採用すれぼ同様の強度のコー クスが得られることがわかる。これらのことは予 備実験によつてたしかめていた結果と同様の傾向 であるが，かさ密度の増加がやはりそれほど大き くなかつたため，高炉用として使用できるほどの コークス強度を示さなかつたのは残念であつた。

3. 押出抵抗 炉によりそれぞれ押出抵抗は異なる けれども，常法と部分予熱法とでは特に差はみと められない。

4. コークスの性状 コークスの工業分析值その他 コークスとしての性状は予熱法によつてとくに変 化はみとめられない。

5. 炉内炭中温度 炉中心部における炭中温度の上 昇状況は常法に比し, $100^{\circ} \mathrm{C}$ 以上に上昇する時間 は予熱炭配合の方が早いにもかかわらず，それ以 後の上昇状態はゆるやかになつている。これは湿 分の減少に応じて熱伝導の状況が変つていること を示しているものと考えられる。また装入直後の 温度変化は湿分の影響によるものであろう。

6. 炉頂空閒部温度 常法の場合は水分の影響があ るため不規則な温度変化を示すが，湿分の減少に ともない予熱炭配合の場合は単なるガスの発生だ けのようになり割り合いスムーズな曲線を描くよ うである。したがつて副産物の生成率に影響をお よぼすような温度変化は特にないものと考察され る。

\section{VIII. 今後の研究課題}

過去 3 ケ年半にわたり, 基礎実験より実炉試験に至 る一連の予熱炭乾留法に関する試験を実施してきた が，結論的には所期の目的を達成したものと考えてい る。しかし現在までの試験結果から未解決の問題点が いくつか残されていることが反省される。これらにつ いては今後の研究課題として取り組んでいくつもりで あるが，以下これらについて略述する。

1. かさ密度に関する研究

予熱炭乾留法において粘結炭のコークス強度が
上昇するのは主としてかさ密度の増加によるもの であるが，かさ密度の増加はコークス炉の大型化 にともない構造上に限界があるし，また押出し困 難を扢こす原因にもなる。かさ密度の変化に影響 を扰よ゙す因子は，(1) 湿分（2）粒度（3）炭質 である。さらにかさ密度の増加は膨張圧の増加と なり，コークス炬にとつては致命的な破壊現象を もたらすことさえある。現在のコークス炉におい ては，かさ密度の限界点は $0.85 \mathrm{~g} / \mathrm{cm}^{3}$ といわ れ，また膨張圧の限界は $0.8 \mathrm{~g} / \mathrm{cm}^{3}$ のかさ密度 の時 $0.14 \mathrm{~kg} / \mathrm{cm}^{2}$ といわれている。また強粘結 炭などでは二次圧が問題だとされている。したが つて予熱炭乾留法を採用するに当つては代表的炭 種についてこれらの関係を十分検討しておかなけ ればならない。

2. 予熱効果の機構解明に関する研究 (I)

同じ粘結炭でも常法と予熱法によつて，同じか さ密度でコークス化を行なつても，予熱法の方が コークス強度が高くなり，また炭種によつてはふ 几囲気や温度が非常に影響をおよぼし，あるいは また予熱放泠後のコークス化性に変化のあること から，単にかさ密度の増加だけがコークス化性向 上に寄与しているとは考えられず，炭質的に変化 があるものか，あるいはまた水分が影響するもの かなどよくわかつていない。炭質的変化があるも のならば，予熱温度，ふん囲気などに対する炭質 変化を追求しなければならず，水分の影響ならば 予熱でなく単に乾燥のみで十分であるとも考えら れるので，これらの関係についてさらに深く検討 する必要がある。

3. 予熱効果の機構解明に関する研究 (II)

現在高炉用コークスの製造には強粘結炭は約 $50 \%$ 配合している。予熱炭乾留法を採用すれば その 10２0\% を微粘結炭または非粘結炭である 一般炭とおきかえることが可能である。このこと は国内炭活用の立場から，この試験の一つの目的 であつたが，予熱法を採用すれば何故一般炭の配 合が可能となるかはまだ明らかでない。したがつ て弱粘結炭の予熱効果とともに一般炭の予熱効果 についても検討する必要がある。

4. 予熱効果の副産物におよぼす影響に関する研究 予熱炭の研究において，諸外国では予熱方法に 種々の方法が採用され，その乾留時生成する副産 物およびコークスの量が常法に比して変化があ り，また質的にも変化があるとされている。炭種 
や試験方法が異なるので，それらの増減について ははつきりした結論はひきだされていない。した がつてわが国で予熱法を実炉に採用した時，現在 用いている炭種について量および質的にいかなる 変化があるかについて検討を行なつておく必要が ある。

5. 予熱炭装入法に関する研究

予熱炭の装入にあたつて, 石炭が流体化してい るため，その作業が非常に簡易化される。したが つて現在アメリカにおいて試験中のパイプチャー ジ方式が採用できる。その場合予熱炭のキャリャ 一ガスとしてスチーム，COGが考えられるが, 化学工学的な考察と高温のコークス炉への接続に 関する機構について研究試験しパイプチャージ方 式のわが国における実用化をはかる必要がある。 また他の方式による装入法の開発も検討してみる 必要がある。

6. 予熱炭のオイリングに関する研究

予熱炭処理において炭じんの発生をおさえるこ とはなにをおいても重要なことである。運搬には 密閉式のフローコンベヤやパイプ輸送が有効であ るが，混炭の場合のようにオープンの場所での炭 じんの放散はさけられない。これ学防ぐ方法とし てオイリングを行なう方法がある。これは炭じん 防止と装入かさ密度の調整に役立つもので有勃の ようである。したがつてオイリングについて䄃討 を行なうとともにコークス炉や副産物におよぼす 影響などについて検討する必要がある。

\section{IX. 結 論}

予熱炭乾留法について実炉による予備試験にひきつ うきき, 今回は強粘結炭と弱粘結炭, および強粘結炭を 一般炭に一部おきかえた部分予熱法に関する実炉試験 を実施した。ただ原料炭の入手が不如意であつたこと と, 操業中のコークス炉に悪影響をあたえてはならな 、配慮から，炭種を選定し，配合割合を定め, かさ密 度も最高 $0.8 \mathrm{~g} / \mathrm{cm}^{3}$ までとして試験した。それでも 予熱効果は明らかにあらわれ，コークス炉の生産性は 向上し, 強粘結炭の配合量は 30\% 以下でよく, 国内 炭を多量に使用して強度の高いコークスが得られた。 また一般炭も 10２0\% は混炭可能であることもたし かめることができた。これら実炉試験により，わが国 においても予熱炭乾留法または乾燥炭乾留法は実施可 能であるとの見通しと確信を得た。今後は残された問 題点についてきめの細かい試験研究を行なつていくつ もりである。

本試験にあたり，全面的に協力を賜わつた北海道崖 鉱汽船K.K. の各位に深甚なる謝意を表する。

\section{文献}

1) 佐藤春三, 吉田晋, 燃協誌, 44, No. 456, 239 44 (1955)

2) 吉田晋，第39回コークス特別会にて講演，昭 45 .

3) Koppers Handbuch der Brennstoff-technik, p. 199, (1953)

4) Anon; Archiv für das Eisenhüttenwesen, 147

5) J. D. Doherty et al.; Blast furnace \& Steel Plant, 1251, March (1962)

\title{
Test of the Preheating Carbonization Process at a Coke Oven (II)
}

\author{
by Haruzo Sato \& Susumu Yoshida \\ (Coal Mining Research Center, Japan)
}

SYNOPSIS : - This report described the results of preheated coal carbonization test on a commercial coke oven, and we used experimental arrangements of our previous report.

Used coals were following,

weakly coking coal.......... Yubari-Tokugo-Bifun coal (Japan)

slightly coking coal..........Bibai coal (Japan)

strong coking coal.........Vicary Creek coal (Canada)

For this test we based on partial preheating method, that was, preheated weakly coking coal and slightly coking coal, but strong coking coal untreated.

Results of this test, mixing weight of strong coking coal should be sufficient by half, comparing with untreated charging coal by same blending ratio, and we obtained same coke strength.

Then it could be substituted with slightly coking coal. On the other hand, throughput of coke oven improved about $20 \%$ by increasing bulk densiy and shortening coking time.

We recognized a possibility to introduce the preheating process for full scale coke oven without any troubles. 